\title{
Kekuatan Hukum Irah-Irah Eksekutorial Pada Grosse Akta Sebagai Dasar Eksekusi Jaminan
}

\author{
The Legal Strength of the Executive Execution in the Grosse Deed as the Basis \\ for Execution of Collateral
}

\author{
Mohammad Amri Gede1, Nurfaidah Said ${ }^{2}$, Muhammad Ilham Arisaputra ${ }^{3}$ \\ 1. Fakultas Hukum Universitas Hasanuddin, Indonesia. E-mail: mamrygede@gmail.com \\ 2. Fakultas Hukum Universitas Hasanuddin, Indonesia. E-mail: nurfaidahsaid@unhas.ac.id \\ 3. Fakultas Hukum Universitas Hasanuddin, Indonesia. E-mail: ilhamarisaputra@gmail.com
}

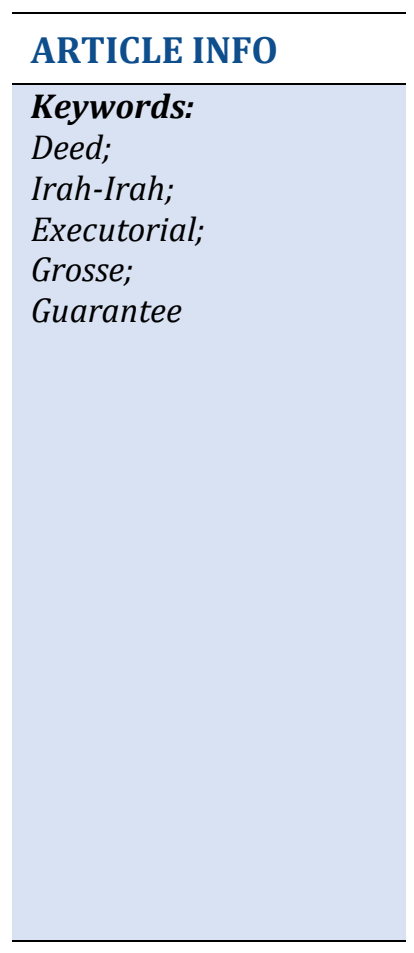

\section{INFO ARTIKEL}

\begin{tabular}{l}
\hline Kata kunci: \\
Akta; \\
Irah-Irah; \\
Eksekutorial; \\
Grosse; \\
Jaminan \\
\\
\hline
\end{tabular}

\begin{abstract}
This research is to find out and analyze the authority and nature of the position of notary in making a grosse deed of acknowledgment of debt that has an executorial prominence associated with the position of a notary public officer. This research is a normative legal research using a statutory approach, conceptual approach, and historical approach. The results showed that the authority of a notary in making a debt recognition certificate which has an executorial role is associated with the position of the notary public as an attribute. Grosse deed of recognition of debt as a legal product from a notary that is part of the executive does have the same characteristics as a judicial product, so that in execution it is necessary to determine from the court as a form of legality for the execution of the grosse deed of debt recognition. The executives in the grosse deed of recognition of debt do not have direct executive power, but must be determined by the court as a form of legality of the execution. However, the position of the grosse deed of recognition of debt which has an executorial decree as a copy of one million deed is different from copies of other deeds that do not have an executorial decree. The legal strength of a grosse deed of recognition of debt that has an executorial purpose is only to provide legal certainty regarding the existence of a legal relationship of debt and also provide legal certainty to creditors regarding the execution of which is no longer necessary through filing a lawsuit, but only based on the request of the creditor.
\end{abstract}

\section{ABSTRAK}

Penelitian ini untuk mengetahui dan menganalisis kewenangan dan hakikat kedudukan notaris dalam membuat grosse akta pengakuan hutang yang memiliki irah-irah eksekutorial dikaitkan dengan kedudukan notaris sebagai pejabat umum. Penelitian ini merupakan penelitian hukum normative dengan menggunakan pendekatan perundang-undangan, pendekatan konseptual, dan pendekatan sejarah. Hasil penelitian menunjukkan bahwa kewenangan notaris dalam membuat grosse akta pengakuan hutang yang memiliki irah-irah eksekutorial dikaitkan dengan kedudukan notaris sebagai pejabat umum adalah bersifat atributif. Grosse akta pengakuan hutang 
sebagai produk hukum dari notaris yang notabene bagian dari eksekutif memang memiliki karakteristik yang sama dengan produk hukum yudikatif, sehingga dalam eksekusinya diperlukan penetapan dari pengadilan sebagai bentuk legalitas dari pelaksanaan eksekusi grosse akta pengakuan hutang. Irah-irah eksekutorial pada grosse akta pengakuan hutang pada hakikatnya tidak mempunyai kekuatan eksekutorial langsung, tetapi harus melalui penetapan dari pengadilan sebagai bentuk legalitas pelaksanaan eksekusi. Namun demikian, kedudukan grosse akta pengakuan hutang yang memiliki irah-irah eksekutorial sebagai salinan dari suatu minuta akta berbeda dengan salinan dari akta-akta lainnya yang tidak memiliki irah-irah eksekutorial. Kekuatan hukum dari suatu grosse akta pengakuan hutang yang memiliki irah-irah eksekutorial hanya untuk memberikan kepastian hukum mengenai adanya suatu hubungan hukum utang piutang saja serta memberikan kepastian hukum kepada kreditor perihal eksekusinya yang tidak perlu lagi melalui pengajuan gugatan, namun hanya didasarkan atas permohonan kreditor.

\section{Pendahuluan}

Faktor permodalan merupakan syarat yang mempunyai peranan yang sangat penting ketika melaksanakan pembangunan di bidang ekonomi ini. Dalam rangka memelihara kesinambungan pembangunan tersebut yang para pelakunya meliputi Pemerintah maupun masyarakat sebagai orang perseorangan dan badan hukum, sangat diperlukan dana dalam jumlah yang sangat besar. Dengan meningkatnya kegiatan pembangunan, meningkat juga keperluan akan tersedianya dana yang sebagian besar diperoleh melalui kegiatan perkreditan.

Pada setiap pemberian kredit oleh bank pasti akan dihadapkan pada suatu risiko, yaitu risiko kredit bermasalah atau kredit macet. ${ }^{1}$ Untuk itu, maka kehadiran notaris dalam pemberian kredit oleh Bank sebagai pejabat umum yang berwenang membuat akta otentik sangat dibutuhkan dalam rangka memberikan kepastian hukum.

Selain memerlukan jasa notaris sebagai pejabat yang berwenang membuat akta perjanjian kredit sebagai perjanjian pokoknya, Bank juga memerlukan peran Notaris dalam pengikatan agunan kredit. Seperti diketahui bahwa bank dalam menyalurkan kredit selalu mengedepankan prinsip kepercayaan dan kehati-hatian. Apabila Bank telah memperoleh keyakinan atas kemampuan calon debiturnya untuk mengembalikan kredit yang disalurkan, maka sebetulnya bank tidak perlu meminta jaminan tambahan. Namun, untuk menerapkan prinsip kehati-hatian bank, maka untuk setiap penyaluran kredit kepada masyarakat, bank akan meminta adanya jaminan tambahan berupa jaminan perorangan atau jaminan kebendaan untuk lebih menambah keyakinan Bank bahwa nantinya debitur akan mampu melunasi kreditnya tepat waktu. Jaminan yang dimaksudkan di sini pada praktiknya lebih sering berupa jaminan kebendaan, baik yang dibebankan fidusia (untuk benda bergerak) ataupun dibebankan hak tanggungan (untuk jaminan berupa tanah). Adanya jaminan ini dapat menambah keyakinan Bank apabila debitur wanprestasi, maka

1 Riyo Wuryanto dan Noor Saptanti, "Efektivitas Grosse Akta Pengakuan Hutang dalam Praktik Pemberian Kredit Perbankan di Surakarta," Jurnal Repertorium 5, no. 1 (2018): 205. 
Bank dapat mengeksekusi jaminan yang diserahkan oleh debitur untuk memperoleh pelunasan atas kredit yang disalurkan.

Konteks inilah diperlukan peran Notaris sebagai pejabat umum yang dapat membuat aktaakta yang terkait dengan pengikatan jaminan/agunan tersebut, seperti pembuatan Akta Jaminan Fidusia, Surat Kuasa Membebankan Hak Tanggungan, Akta Cessie, dan lain sebagainya yang nantinya akan dilanjutkan dengan pendaftaran pada lembaga-lembaga terkait seperti pada Kementerian Hukum dan HAM untuk fidusia dan pendaftaran hak tanggungan pada Kantor Pertanahan setempat untuk agunan yang berupa hak atas tanah. ${ }^{2}$ Setelah didaftarkan pada lembaga- lembaga tersebut, maka akan lahir sertipikat pengikatan jaminan seperti Sertipikat Jaminan Fidusia atau Sertipikat Hak Tanggungan yang memiliki kekuatan eksekutorial.

Grosse akta pengakuan hutang merupakan salah satu produk hukum dari Notaris yang diharapkan dapat memberikan kepastian hukum bagi pelaku perbankan. ${ }^{3}$ Dalam Pasal 1 angka 11 Undang-Undang Nomor 2 Tahun 2014 tentang Perubahan Atas Undang-Undang Nomor 30 Tahun 2004 Tentang Jabatan Notaris (selanjutnya disebut UUJN) ditentukan bahwa "Grosse Akta adalah salah satu salinan Akta untuk pengakuan hutang dengan kepala Akta "DEMI KEADILAN BERDASARKAN KETUHANAN YANG MAHA ESA", yang mempunyai kekuatan eksekutorial".

Salah satu akta yang biasanya dibuat dalam bentuk Grosse Akta adalah Akta Pengakuan Hutang. Akta pengakuan hutang merupakan salah satu bentuk perbuatan hukum sepihak yang secara sukarela yang dibuat oleh debitur dalam rangka menjamin dan/atau menambah keyakinan kreditor dalam perjanjian utang piutang. Grosse akta pengakuan hutang ini biasanya dibuat debitur dalam bentuk akta otentik. Keberadaan grosse akta pengakuan hutang ini dalam hukum jaminan mempunyai peran besar, khususnya di bidang perkreditan. Keberadaan grosse akta pengakuan hutang memberikan hak-hak istimewa kepada kreditor untuk melakukan tindakan hukum (eksekusi) terhadap suatu benda tertentu yang secara khusus disebutkan dalam grosse akta tersebut. ${ }^{4}$

Kekuatan eksekutorial terhadap grosse akta mengandung arti bahwa pelaksanaan (eksekusi) dari grosse akta tersebut dipersamakan dengan putusan hakim yang telah memiliki kekuatan hukum tetap, sehingga eksekusi dari grosse akta tersebut dapat langsung dilakukan tanpa melalui gugatan biasa. Dengan demikian, penyelesaian perkara melalui eksekusi grosse akta ini merupakan pengecualian (exceptional) dari asas peradilan umum, yaitu bahwa seseorang dapat menyelesaikan sengketa berdasarkan gugatan atau legal proceedings. ${ }^{5}$

2 D. O. Setiabudhi et al., "Collective land certification policy for improving good land governance," IOP Conference Series: Earth and Environmental Science 343, no. 1 (2019): 1-5.

3 Elza Sylvania Pittaloka dan Pranoto, "Permasalahan dalam Pelaksanaan Eksekusi Grosse Akta Pengakuan Hutang," Jurnal Privat Law 4, no. 1 (2016): 79-86.

4 M. Yahya Harahap, Ruang Lingkup Permasalahan Eksekusi Bidang Perdata, 5 ed. (Jakarta: Gramedia Pustaka Utama, 1996), 18.

5 Ibid., 37. 
Grosse akta pada prinsipnya dibuat dengan tujuan untuk memudahkan kreditor dalam menagih piutangnya. Namun dalam praktiknya tujuan ini tidak semudah itu, kreditor tidak dapat serta merta melakukan eksekusi terhadap barang jaminan yang dijaminkan kepadanya. Di konteks inilah biasanya untuk mengeksekusi barang jaminan tersebut, kreditor harus mengajukan permohonan kepada Pengadilan untuk kemudian dapat dieksekusi. ${ }^{6}$

Pada dasarnya fungsi adanya suatu grosse akta dimaksudkan untuk kemudahan dalam hal eksekusi apabila terjadi wanprestasi. Dengan grosse akta, maka kreditor dapat langsung menggunakan hak eksekusinya tanpa melalui proses gugatan sehingga kreditor dapat langsung mengajukan permohonan eksekusi ke pengadilan. Jadi, dengan grosse akta harusnya kreditor dapat melakukan parate eksekusi terhadap barang jaminan ataupun terhadap harta kekayaan debitur tanpa melalui fiat pengadilan.

Pada tataran praktis, masih banyak permasalahan yang dapat menghambat jalannya eksekusi grosse akta pengakuan hutang yang ditujukan kepada pengadilan sehingga sering kali permohonan eksekusi grosse akta pengakuan hutang ditolak oleh pengadilan yang berwenang meskipun grosse akta tersebut telah memenuhi syarat formil. Alasanalasan tersebut antara lain: ${ }^{7}$

a. Isinya tidak merupakan pengakuan hutang sepihak;

b. Jumlahnya tidak pasti karena dalam akta pengakuan hutang tersebut ditentukan bunga dan/atau denda;

c. Berdasarkan keberatan secara tertulis dari debitur terhadap eksekusi grosse akta dengan alasan:

1) Bahwa jumlahnya tidak pasti karena dari jumlah yang tertera pada grosse akta pengakuan hutang sebagian telah dibayar dengan menunjukkan kuitansi tanda terima pembayaran dari kreditor permohonan eksekusi.

2) Meskipun judulnya grosse akta pengakuan hutang, isinya bukan pengakuan hutang sepihak karena dalam grosse akta tersebut disebutkan/dimasukkan perjanjian yang menjadi sumber hutang tersebut seperti perjanjian jual beli dan lain-lain yang menimbulkan kewajiban pada debitur untuk membayar sejumlah uang tertentu sehingga menurut ketua pengadilan yang menangani permohonan eksekusi tersebut, grosse akta tersebut tidak memenuhi syarat materiil untuk dikabulkan karena isinya bukan pengakuan hutang murni/sepihak.

Pada Tahun 1985, Mahkamah Agung RI mengeluarkan Fatwa Nomor 213/229/85/II/Um.Tu/Pdt tertanggal 16 April 1985 yang menyatakan bahwa: ${ }^{8}$

6 Victor M. Situmorang dan Cormentyna Sitanggang, Grosse Akta Dalam Pembuktian dan Eksekusi (Jakarta: Rineka Cipta, 1998), 3.

7 Shendy Vianni Rangian, "Pelaksanaan Eksekusi Grosse Akta Pengakuan Hutang Dalam Penyelesaian Sengketa Kredit Macet Perbankan," Calyptra: Jurnal Ilmiah Mahasiswa Universitas Surabaya 4, no. 1 (2015): 5 .

8 Ibid., 11. 
Dalam suatu grosse akta tidak dapat ditambah persyaratan-persyaratan lain tersebut berbentuk perjanjian menimbulkan kegelisahan di kalangan perbankan terutama yang menyangkut perjanjian kredit yang begitu banyak persyaratannya. Isi suatu perjanjian, kecuali para pihak yang mengadakan perjanjian tersebut minimal memuat: (a) Jumlah hutang; (b) Bunga; (c) Jangka Waktu; (d) Keadaan mana kredit dapat ditagih (opeisbaarheid atau keadaan default); (e) Jaminan.

Dapat atau tidaknya dilaksanakan eksekusi atas suatu grosse akta sebagaimana dimaksudkan oleh Pasal 224 HIR atau Pasal 258 RBg merupakan wewenang sepenuhnya dari hakim yang bersangkutan. Sejak dekade 1980-an pengadilan di Indonesia mengambil sikap berbeda, antara lain dapat dilihat dari surat-surat yang pada waktu itu dikeluarkan oleh Ketua Muda Perdata Tertulis Asikin Kusumah Atmadja (Catatan No. VII/1988/Perdata, Pebruari 1988 yang diselipkan di bawah Putusan No. 1520K/Pdt/1984, tertanggal 31 Mei 1986) yang pada intinya memuat pernyataan yang berisi keberatan (perlawanan) terhadap pelaksanaan eksekusi grosse akta tersebut, dan untuk pelaksanaan eksekusinya harus tunduk pada putusan hakim. ${ }^{9}$

Dengan ketidakmampuan seorang debitur membayar hutangnya, terkadang kreditor ingin segera melakukan penyelesaian atas hutang tersebut melalui eksekusi dengan tetap mengindahkan tahapan-tahapan yang ada sampai pada tahap eksekusi. Namun demikian, terkadang terjadi penolakan dalam eksekusi tersebut karena diperlukan suatu penetapan pengadilan (fiat pengadilan) sehingga menimbulkan ketidakpastian hukum bagi kreditor dan tidak tercapainya kemudahan dalam hal eksekusi grosse akta. Terlebih lagi dengan adanya Surat Edaran Mahkamah Agung Nomor VII/1988 semakin menimbulkan ketidakpastian atas kedudukan grosse akta dengan irah-irah eksekutorialnya ataupun kedudukan kreditor pemegang grosse akta sebagai kreditor preferen.

\section{Metode}

Penelitian ini merupakan penelitian hukum normatif. Pendekatan yang dipergunakan dalam penelitian ini adalah menggunakan pendekatan perundang-undangan (statute approach), pendekatan konseptual (conceptual approach), dan pendekatan sejarah (historical approach). ${ }^{10}$ Dengan menggunakan ketiga pendekatan tersebut diharapkan menjadi suatu kesatuan yang saling melengkapi dan nantinya dapat memperoleh hasil penelitian yang komprehensif.

\section{Kewenangan dan Kedudukan Notaris dalam Membuat Grosse Akta Pengakuan Hutang yang Memiliki Irah-Irah Eksekutorial}

Notaris merupakan pejabat umum yang berwenang untuk membuat segala jenis akta yang dikehendaki oleh masyarakat sepanjang tidak bertentangan dengan peraturan perundang-undangan, kesusilaan dan ketertiban umum. Pada situasi seperti sekarang ini,

9 Mochammad Taufiq Arifin, "Eksekusi Grosse Akta Merujuk Pada Pasal 224 HIR dan Putusan Mahkamah Agung," Jurnal Hukum dan Kenotariatan 3, no. 1 (2019): 101-102.

10 Peter Mahmud Marzuki, Penelitian Hukum (Jakarta: Kencana Prenada Media Group, 2009), 93. 
peran seorang Notaris semakin diperlukan dalam segala lini kehidupan, termasuk dalam dunia perbankan. Berdasarkan ketentuan Pasal 1 angka 1 Undang-Undang Nomor 2 Tahun 2014 tentang Perubahan atas Undang-Undang Nomor 30 Tahun 2004 Tentang Jabatan Notaris (untuk selanjutnya disebut dengan UUJN) Notaris adalah "Pejabat umum yang berwenang untuk membuat akta otentik dan kewenangan lainnya sebagaimana dimaksud dalam undang- undang ini".

Akta merupakan produk hukum yang dibuat oleh seorang Notaris. Berdasarkan ketentuan Pasal 1868 KUHPerdata akta otentik adalah suatu tulisan yang dibuat dalam bentuk yang ditentukan oleh undang-undang atau di hadapan pejabat umum yang berwenang untuk itu di tempat akta itu dibuat. Terdapat begitu banyak jenis akta yang dapat dibuat oleh seorang Notaris, salah satunya adalah akta pengakuan hutang. Ketentuan Pasal 1 angka 11 UUJN yang mengatur mengenai akta pengakuan hutang menentukan bahwa "Grosse akta adalah salah satu akta untuk pengakuan utang dengan kepala akta "Demi Keadilan Berdasarkan Ketuhanan Yang Maha Esa" yang mempunyai kekuatan eksekutorial.

Grosse akta pengakuan hutang merupakan suatu kelanjutan dari perjanjian hutang piutang antara kreditor dengan debitur yang merupakan perjanjian tersendiri dan lepas dari perjanjian utang piutang, sehingga kehadirannya dapat dianggap sebagai suatu perjanjian yang mengikuti atau sebagai tambahan pada perjanjian hutang piutang atau perjanjian pokok. Praktik pemberian kredit pada lembaga perbankan sering mempraktikkan seorang debitur diikat dengan suatu jaminan pokok dan jaminan tambahan yang kadang diformulasikan dalam bentuk akta pengakuan hutang, baik dalam bentuk akta otentik (notaril) maupun dalam bentuk akta di bawah tangan. Kedua bentuk akta pengakuan hutang, baik pengakuan hutang dalam bentuk akta di bawah tangan maupun dalam bentuk akta notaril, merupakan akta pengakuan hutang sepihak. Artinya bahwa pengakuan hutang tersebut dibuat oleh pihak debitur saja sebagai pihak yang berhutang yang di dalamnya mengandung janji-janji yang intinya adalah manakala debitur lalai melaksanakan prestasi yang diperjanjikan, maka kreditor dapat melaksanakan eksekusi terhadap benda yang secara khusus disebutkan dalam akta tersebut.

Terhadap akta pengakuan hutang yang dibuat debitur di hadapan seorang notaris, maka kekuatan hukumnya adalah sempurna dalam arti mempunyai kekuatan sama dengan putusan pengadilan yang telah mempunyai kekuatan hukum yang tetap. ${ }^{11}$ Kekuatan ekskutorial grosse akta memberikan kedudukan istimewa bagi pihak kreditor dalam hal pelaksanaan eksekusinya bilamana debitur wanprestasi dalam melaksanakan prestasi yang diperjanjikannya. Dikatakan mempunyai kedudukan istimewa dibanding dengan kreditor-kreditor lain oleh karena selain mempunyai hak untuk didahulukan, grosse akta juga menjadi satu-satunya akta otentik yang bukan putusan pengadilan yang mempunyai titel eksekutorial. Jadi keistimewaan grosse akta pengakuan hutang disebabkan adanya frasa "Demi keadilan berdasarkan Ketuhanan yang maha Esa" karena dengan kata-kata ini, maka mempunyai kekuatan sama dengan kekuatan pengadilan yang telah berkekuatan

11 Muhammad Ilham Arisaputra et al., "Akuntabilitas Administrasi Pertanahan dalam Penerbitan Sertifikat," Mimbar Hukum 29, no. 2 (2017): 276-291. 
hukum tetap. Hal yang demikian menurut hukum dapat dilakukan sita eksekusi dalam rangka pemenuhan hutang-hutang debitur tanpa harus terlebih dahulu melakukan gugatan ke pengadilan.

Apa yang dikemukakan di atas menarik untuk penulis analisa. Ada beberapa hal yang menarik perhatian penulis untuk menganalisis mengenai grosse akta ini, yakni:

\subsection{Grosse akta memiliki kekuatan eksekutorial}

Sebagaimana diketahui bahwa dalam Pasal 1 angka 11 Undang-Undang Nomor 2 Tahun 2014 tentang Perubahan Atas Undang-Undang Nomor 30 Tahun 2004 tentang Jabatan Notaris ditentukan bahwa Grosse Akta adalah salah satu salinan Akta untuk pengakuan hutang dengan kepala Akta "DEMI KEADILAN BERDASARKAN KETUHANAN YANG MAHA ESA", yang mempunyai kekuatan eksekutorial. Berdasarkan Surat Edaran Mahkamah Agung Nomor 213/229/85/Um-TU/Pdt menjelaskan pengertian grosse akta seperti yang dimaksud Pasal 224 HIR atau Pasal 258 RBg adalah suatu akta autentik yang berisi pengakuan hutang dengan perumusan semata-mata suatu kewajiban untuk membayar/melunaskan sejumlah uang tertentu. Hal ini berarti dalam suatu grosse akta tidak dapat ditambahkan persyaratan-persyaratan tersebut berbentuk perjanjian.

Dari penjelasan di atas, maka suatu grosse akta merupakan akta otentik yang pada prinsipnya merupakan kewenangan notaris untuk membuatnya. Pasal 55 UUJN menentukan bahwa:

(1) Notaris yang mengeluarkan Grosse Akta membuat catatan pada minuta akta mengenai penerima Grosse Akta dan tanggal pengeluaran dan catatan tersebut ditandatangani oleh Notaris.

(2) Grosse Akta pengakuan utang yang dibuat di hadapan Notaris adalah Salinan Akta yang mempunyai kekuatan eksekutorial.

(3) Grosse Akta sebagaimana dimaksud pada ayat (2) pada bagian kepala akta memuat frasa "DEMI KEADILAN BERDASARKAN KETUHANAN YANG MAHA ESA", dan pada bagian akhir atau penutup akta memuat frasa "diberikan sebagai grosse pertama", dengan menyebutkan nama orang yang memintanya dan untuk siapa grosse dikeluarkan serta tanggal pengeluarannya.

(4) Grosse Akta kedua dan selanjutnya hanya dapat diberikan kepada orang sebagaimana dimaksud dalam Pasal 54 berdasarkan penetapan pengadilan.

Terdapat syarat bentuk dan syarat isi dari suatu grosse akta, yakni sebagai berikut: 12

a. Kepala grosse akta Pengakuan Hutang. Pada bagian kepala membuat kata-kata: "Demi Keadilan Berdasarkan Ketuhanan Yang Maha Esa” (pasal 224 HIR jo. Pasal 38 ayat 2 UUJN). Apabila pada bagian kepala grosse akta pengakuan hutang tidak mempunyai kekuatan eksekutorial. Bila Notaris lupa atau lalai mencantumkan kata-kata tersebut

12 Ibid., 105-106. 
dalam kepala grosse akta pengakuan hutang maka Notaris akan dikenakan sanksi denda.

b. Nomor grosse akta pengakuan hutang. Nomor grosse akta pengakuan hutang sama dengan akta autentiknya. Walaupun tidak ada ketentuan dalam UUJN yang menerapkan sanksi bagi Notaris yang mencantumkan nomor pada setiap aktanya, namun dengan pemberian nomor pada setiap akta tentunya dapat membantu administrasi dan menguntungkan bagi notaris sendiri untuk arsipnya.

c. Judul akta. Dalam peraturan jabatan notaris tidak ada ketentuan notaris harus mencantumkan judul. Walaupun demikian apabila suatu akta dibuat tanpa judul tentunya akan membingungkan notaris dan para pihak yang memuat akta tersebut.

d. Awal akta grosse akta Pengakuan Hutang. Pada awal akta grosse akta pengakuan hutang harus dimuat hari dan tanggal dibuatnya akta, nama lengkap para pihak dan tempat kedudukan notaris serta sanksi-sanksi intrumentair. Apabila Notaris tidak memuat syarat ini maka notaris akan dikenakan denda atau akta notaris hanya sebagai akta di bawah tangan.

e. Komparisi. Komparisi adalah kewenangan menghadap dari masing-masing pihak di depan pejabat yang berwenang untuk bertindak hukum untuk mana akta tersebut dibuat.

f. Premis. Dalam peraturan jabatan notaris tidak ada ketentuan yang mengharuskan pemuatan premis dalam akta autentik. Pada bagian premis grosse akta pengakuan hutan dapat disebutkan perjanjian yang menjadi dasar dilakukannya utang. Bila dasar pengakuan hutang terdapat bunga atau denda maka perhitungan jumlah seluruh hutang dicantumkan pada bagian premis akta.

g. Isi grosse akta Pengakuan hutang:

1) Pengakuan hutang sepihak oleh debitur.

2) Kewajiban membayar sejumlah uang tertentu.

3) Dalam jangka waktu tertentu.

4) Tempat pembayaran.

5) Opeisbaarheid (dapat ditagih)

Dari penjelasan di atas, maka dapat dipertegas oleh penulis bahwa suatu grosse akta pengakuan hutang merupakan suatu akta otentik yang wewenang pembuatannya diberikan kepada notaris sebagai pejabat umum. Ghansam Anand ${ }^{13}$ menjelaskan bahwa:

Notaris merupakan suatu profesi yang menjalankan sebagian kekuasaan negara di bidang hukum privat, yang bertugas untuk membuat alat bukti berupa akta otentik yang mempunyai kekuatan pembuktian sempurna dan oleh karena itu, profesi notaris juga merupakan suatu profesi dan jabatan kepercayaan, maka seorang notaris harus mempunyai perilaku yang baik dan menjaga keluhuran harkat dan martabat profesinya.

13 Ghansam Anand, Karakteristik Jabatan Notaris di Indonesia (Surabaya: Zifatama Publisher, 2014), 159. 
Lola Rosalina ${ }^{14}$ juga menjelaskan bahwa notaris adalah pejabat umum yang diberikan kewenangan oleh undang-undang untuk membuat akta yang dapat dijadikan alat bukti oleh para pihak atas perbuatan hukum yang dilakukannya. Notaris berhak menggunakan lambang negara dalam menerbitkan produk hukumnya sehingga dengan penggunaan lambang negara tersebut notaris dipandang sebagai jabatan yang menjalankan sebagian kekuasaan negara.

Jadi, notaris merupakan suatu jabatan yang diberikan kewenangan oleh negara untuk menjalankan sebagian tugas dan fungsi pemerintah untuk memberikan pelayanan kepada masyarakatnya, dalam hal ini notaris diberikan kewenangan untuk membuat alat bukti berupa akta otentik yang karakteristiknya juga sesuai dengan karakteristik atau ciri-ciri dari suatu profesi. ${ }^{15}$ Dari penjelasan ini, maka penulis berpendapat bahwa notaris sebagai suatu jabatan pada hakikatnya menjalankan fungsi pelayanan publik ${ }^{16}$, sehingga jika dikategorikan dalam konteks Trias Politika, maka notaris pada hakikatnya menempati cabang kekuasaan eksekutif.

Kedudukan notaris dalam pembagian kekuasaan sebagaimana diuraikan di atas menempati cabang kekuasaan eksekutif, yakni cabang kekuasaan untuk melaksanakan undang-undang. Kekuasaan melaksanakan undang-undang dipegang oleh Kepala Negara. Kepala Negara tentu tidak dapat dengan sendirinya menjalankan segala undang-undang ini sehingga kekuasaan dari kepala Negara dilimpahkan (didelegasikan) kepada pejabatpejabat pemerintah/Negara yang bersama-sama merupakan suatu badan pelaksana undang-undang (Badan Eksekutif).

Meskipun UUD 1945 memang secara tegas tidak menyebutkan mengenai Trias Politika, tapi secara implisit bisa ditelaah bahwa Indonesia menghendaki pembagian kekuasaan. Hal ini jelas dari pembagian bab dalam Undang-Undang Dasar 1945. Misalnya Bab II tentang Majelis Permusyawaratan Rakyat, Bab III tentang Kekuasaan Pemerintahan Negara, Bab VII tentang Dewan Perwakilan Rakyat dan Bab IX tentang Kekuasaan Kehakiman. Kekuasaan legislatif dijalankan oleh Presiden bersama-sama dengan DPR. Kekuasaan eksekutif dijalankan oleh Presiden dibantu oleh menteri-menteri, sedangkan kekuasaan yudikatif dijalankan oleh Mahkamah Agung dan lain-lain badan.

Pembagian kekuasaan yang ada di Indonesia merupakan sebuah konsekuensi dasar dari pemberlakuan sistem demokrasi. Dengan sistem pemerintahannya adalah Presidensial, maka kabinet tidak bertanggungjawab kepada Dewan Perwakilan Rakyat dan oleh karena itu tidak dapat dijatuhkan/diberhentikan oleh Dewan Perwakilan Rakyat dalam masa jabatannya. Sebaliknya, Presiden juga tidak dapat membubarkan Dewan Perwakilan Rakyat. Jadi, pada garis besarnya, ciri-ciri Trias Politika dalam arti pembagian kekuasaan terlihat dalam sistem ketatanegaraan Indonesia.

14 Lola Rosalina, Notaris/PPAT Kota Makassar. Wawancara Tanggal 20 Oktober 2019

15 Ibid.

16 Anshori Ilyas, Muhammad Ilham Arisaputra, dan Mustafa Bola, Kontrak Publik (Makassar: UPT Unhas Press, 2017). 
Konsep Trias Politika dalam pandangan penulis pada hakikatnya untuk memberikan pembatasan terhadap kekuasaan negara. Sistem desentralisasi yang dianut dalam sistem ketatanegaraan Indonesia menunjukkan adanya pembagian kekuasaan secara vertikal, sedangkan secara horizontal pembagian kekuasaan terlihat pada pelaksanaan fungsi lembaga-lembaga negara. Menurut Edie Toet Hendratno ${ }^{17}$ bahwa di Indonesia, pembagian kekuasaan secara vertikal tercermin dalam hubungan pemerintah pusat dan pemerintah daerah sebagaimana ditentukan dalam UUD NRI 1945 bahwa Pemerintah Daerah menjalankan otonomi seluas-luasnya, kecuali urusan pemerintahan yang oleh undangundang ditentukan sebagai urusan pemerintah pusat.

Secara teoretis, pembagian kekuasaan menjadi 3 (tiga) cabang kekuasaan, yakni eksekutif, yudikatif, dan legislatif, maka ada 3 teori yang sering ditawarkan. Pertama, separation of powers yang berciri tidak menerima kehadiran lembaga-lembaga penunjang. Kedua, separation of function yang berciri masih bisa menerima kehadiran lembaga penunjang lainnya sepanjang berhubungan dengan fungsi eksekutif, legislatif, atau yudikatif. Sedangkan yang ketiga adalah check and balances yang berciri menerima sepenuhnya kehadiran lembaga penunjang lain sebagai bagian prinsip kekuasaan ke-4 atau ke-5 dan seterusnya dari cabang kekuasaan legislatif, yudikatif, dan eksekutif.

Merujuk penjelasan tersebut di atas, maka dalam sistem pembagian kekuasaan ini, kedudukan notaris sebagai pejabat umum ditempatkan sebagai bagian dari cabang kekuasaan eksekutif dengan tugas dan wewenangnya memberikan pelayanan publik kepada masyarakat dalam hal pembuatan akta otentik dan kewenangan lainnya yang ditentukan dalam undang-undang, dalam hal ini adalah UUJN. Salah satu kewenangan yang diberikan oleh UUJN adalah membuat grosse akta pengakuan hutang.

Pada prinsipnya pekerjaan yang dilakukan oleh Notaris mempunyai keterikatan dengan kekuasaan yudikatif, terlebih lagi dengan diberikannya kewenangan pembuatan grosse akta pengakuan hutang yang memiliki irah-irah eksekutorial yang dipersamakan dengan keputusan pengadilan yang telah memiliki kekuatan hukum yang tetap. Grosse akta pengakuan hutang memiliki irah-irah eksekutorial yang dipersamakan dengan keputusan pengadilan, namun sejatinya irah-irah pada grosse akta pengakuan tersebut tidak bisa dimaknai memiliki kekuatan eksekusi langsung sesaat setelah debitur dinilai melakukan wanprestasi. Untuk itu, tetap diperlukan putusan pengadilan yang sebenarnya untuk melakukan eksekusi.

\subsection{Grosse akta berbeda dengan akta-akta lainnya yang dibuat oleh notaris}

Notaris merupakan pejabat umum yang diberikan kewenangan oleh undang-undang untuk membuat akta otentik. Pasal 15 ayat (1) UUJN menentukan bahwa:

Notaris berwenang membuat Akta autentik mengenai semua perbuatan, perjanjian, dan penetapan yang diharuskan oleh peraturan perundang-undangan dan/atau

17 Edie Toet Hendratno, Negara Kesatuan, Desentralisasi ,dan Federalisme (Yogyakarta: Graha Ilmu, 2009), 83. 
yang dikehendaki oleh yang berkepentingan untuk dinyatakan dalam Akta autentik, menjamin kepastian tanggal pembuatan Akta, menyimpan Akta, memberikan grosse, salinan dan kutipan Akta, semuanya itu sepanjang pembuatan Akta itu tidak juga ditugaskan atau dikecualikan kepada pejabat lain atau orang lain yang ditetapkan oleh undang-undang.

Dari kewenangan notaris tersebut, terlihat bahwa akta-akta yang mengenai perbuatan hukum atau perjanjian atau penetapan dibedakan dengan grosse akta. Grosse akta, salinan akta, dan kutipan Akta dibuat berdasarkan minuta akta notaris. Perbedaan antara grosse akta, salinan akta, dan kutipan akta dapat dilihat pada Pasal 1 UUJN. Salinan Akta merupakan salinan kata demi kata dari seluruh akta dan pada bagian bawah salinan akta tercantum frasa "diberikan sebagai SALINAN yang sama bunyinya" (Pasal 1 angka 9 UUJN). Kemudian Kutipan Akta merupakan kutipan kata demi kata dari satu atau beberapa bagian dari akta dan pada bagian bawah kutipan akta tercantum frasa "diberikan sebagai KUTIPAN" (pasal 1 angka 10 UUJN). Sedangkan Grosse Akta adalah salah satu salinan akta untuk pengakuan utang dengan kepala akta "Demi Keadilan Berdasarkan Ketuhanan Yang Maha Esa" yang mempunyai kekuatan eksekutorial (Pasal 1 angka 11 UUJN).

Tampak perbedaan mendasar antara grosse akta dengan salinan akta dan kutipan akta terletak pada adanya kekuatan eksekutorial pada suatu grosse akta yang ditandai dengan pencantuman irah-irah eksekutorial pada bagian kepala akta. ${ }^{18}$ Di samping itu, Pasal 55 ayat (1) UUJN juga menentukan bahwa notaris yang mengeluarkan Grosse Akta membuat catatan pada minuta akta mengenai penerima Grosse Akta dan tanggal pengeluaran dan catatan tersebut ditandatangani oleh Notaris.

Menurut pandangan penulis, jika merujuk pada kedudukan notaris sebagai bagian dari kekuasaan eksekutif, maka harusnya grosse akta tidak lagi memiliki irah-irah eksekutorial. Terlebih lagi jika melihat praktiknya bahwa grosse akta pengakuan hutang, meskipun memiliki kekuatan eksekutorial, namun dalam praktik eksekusinya tetap dibutuhkan penetapan oleh pengadilan negeri setempat sehingga irah-irah eksekutorial yang ada pada bagian kepala akta dari suatu grosse akta menjadi kehilangan makna. Pada konteks ini, grosse akta tetap menjadi kewenangan notaris untuk membuatnya, namun irah-irah eksekutorialnya yang ada pada bagian kepala akta dihilangkan. Di samping itu, perlu pula untuk ditegaskan dalam UUJN atau peraturan perundang-undangan lainnya bahwa pelaksanaan eksekusi grosse akta harus dilakukan melalui fiat pengadilan sebagai bentuk check and balances eksekutif dan yudikatif.

\subsection{Eksekusi grosse akta dilakukan dengan mengajukan permohonan eksekusi ke pengadilan}

Pada dasarnya seseorang hanya dapat menyelesaikan suatu sengketa yang diawali dengan suatu gugatan. Akan tetapi dalam beberapa hal undang-undang menentukan pengecualian

18 Ananda Fitki Ayu Saraswati, "Dilematis Eksekusi Hak Tanggungan melalui Parate Executie dan Eksekusi melalui Grosse Akta," Repertorium 2, no. 2 (2015): 56. 
terhadap asas tersebut. Artinya bahwa dalam hal yang ditentukan dengan undang-undang, suatu sengketa langsung dapat dilaksanakan seperti putusan hakim yang telah berkekuatan hukum tetap. Termasuk dalam hal ini adalah grosse akta pengakuan hutang. Eksekusi grosse akta ini merupakan pengecualian dari prinsip eksekusi yang menyatakan bahwa eksekusi hanya dapat dijalankan terhadap putusan Pengadilan yang telah mempunyai kekuatan hukum yang tetap (inkracht van geweisjde). Dalam Pasal $224 \mathrm{HIR}$ atau $258 \mathrm{RBg}$ memperkenalkan eksekusi terhadap bentuk grosse akta yang di dalamnya memuat irah-irah eksekutorial.

Permasalahan mengenai grosse akta dan eksekusi ini sangat erat karena eksekusi terhadap grosse akta pada prinsipnya dapat langsung dieksekusi karena dalam suatu grosse akta sudah terdapat kekuatan eksekutorial sehingga dipersamakan kekuatannya dengan suatu keputusan hakim yang berkekuatan hukum tetap. Logikanya, jika grosse akta mempunyai kekuatan eksekutorial, maka sejatinya kreditor dapat melakukan eksekusi secara langsung tanpa melalui pengadilan. Namun dalam praktiknya, eksekusi terhadap grosse akta pengakuan hutang tetap harus meminta penetapan dari pengadilan. Bahkan terdapat pula grosse akta yang tidak dapat dieksekusi dengan berbagai alasan dan pertimbangan dari hakim.

M. Yahya Harahap menjelaskan bahwa grosse akta memiliki beberapa asas, yakni:19

\section{a. Grosse akta bersifat assesoir.}

Grosse akta merupakan ikatan lanjutan yang lahir dari perjanjian pokok. Terkait hal ini perjanjian pokoknya adalah hubungan hukum perjanjian hutang antara debitur dan kreditur. Dari perjanjian hutang piutang ini, bila para pihak menghendaki, mereka dapat melekatkan perjanjian dalam bentuk grosse akta dengan tujuan memberi jaminan yang lebih pasti bagi pihak kreditur tentang pemenuhan pembayaran hutang serta sekaligus memberi hak kepada kreditur untuk meminta executorial verkoop atas harta kekayaan debitur atau atas barang jaminan sesaat setelah debitur wanprestasi tanpa melalui gugatan perdata biasa. Antara grosse akta dengan perjanjian pokok saling berkaitan.

b. Grosse akta tidak dapat dibagi-bagi.

Bahwa pembayaran atas sebagian jumlah hutang tidak menggugurkan keabsahan dan nilai kekuatan eksekusi (executorial kracht) grosse akta. Asas ini ditegaskan dalam Pasal 1163 KUHPerdata, berlaku juga secara analogis terhadap semua bentuk akta sekalipun Pasal tersebut ditujukan dan diatur dalam pasal-pasal aturan hipotek. Asas ini berlaku pula secara analogis terhadap grosse akta pengakuan hutang.

c. Grosse akta mempunyai nilai kekuatan eksekusi seperti putusan Pengadilan yang telah memperoleh kekuatan hukum tetap.

Apabila semua syarat grosse akta dipenuhi, maka dengan sendirinya menurut hukum grosse akta mempunyai kekuatan eksekusi. Nilai kekuatan eksekusi grosse akta sama

19 Lihat pendapat M. Yahya Harahap dalam Pittaloka dan Pranoto, "Permasalahan dalam Pelaksanaan Eksekusi Grosse Akta Pengakuan Hutang," 82-83. 
dengan nilai kekuatan eksekusi yang melekat pada putusan Pengadilan yang telah memperoleh kekuatan hukum tetap.

d. Perdamaian satu-satunya yang dapat menunda kekuatan eksekusi grosse akta.

Asas ini diatur di dalam Pasal 224 HIR bahwa hanya perdamaian yang dapat menangguhkan eksekusi grosse akta.

e. Eksekusi grosse akta dijalankan atas perintah dan pimpinan Ketua Pengadilan Negeri.

Berdasarkan asas ini executorial verkoop berdasarkan grosse akta dijalankan atas perintah dan di bawah pimpinan Ketua Pengadilan Negeri yang dalam daerah hukumnya orang yang berhutang (debitur bertempat tinggal atau berdiam).

Dari penjelasan M. Yahya Harahap tersebut di atas, maka jelas bahwa setiap eksekusi grosse akta haruslah melalui pengadilan yang berwenang. Eksekusi terhadap grosse akta pengakuan hutang tidak dapat dilakukan secara langsung sesaat setelah debitur melakukan wanprestasi, namun harus dimintakan penetapan eksekusi pada pengadilan negeri setempat. Permohonan penetapan eksekusi ini dapat dimintakan oleh kreditor kepada pengadilan sesaat setelah debitur dianggap melakukan wanprestasi.

Meskipun suatu grosse akta pengakuan hutang dianggap sama kekuatan eksekutorialnya dengan putusan pengadilan, namun kreditor tidak dapat serta merta melakukan eksekusi terhadap harta kekayaan debitur. Hal ini didasarkan pada pemikiran bahwa kedudukan notaris sebagai pejabat umum yang menjalankan atau ditempatkan pada bidang kekuasaan eksekutif, sementara dalam Trias Politica yang dapat memutus dan mengeksekusi suatu perkara hanyalah cabang kekuasaan yudikatif. Untuk itu, meskipun produk hukum notaris yang berupa grosse akta dianggap sama dengan putusan pengadilan, namun grosse akta bukanlah murni putusan pengadilan sehingga tetap dibutuhkan suatu penetapan dari pengadilan. Di samping itu, eksekusi terhadap grosse akta harus tetap dalam pengawasan pengadilan sebagai lembaga yang menjalankan cabang kekuasaan yudikatif sebagai wujud implementasi prinsip check and balances dalam sistem ketatanegaraan Indonesia.

Semua permohonan eksekusi grosse akta pengakuan hutang belum pasti akan diterima, walaupun telah memiliki irah-irah "Demi Keadilan Berdasarkan Ketuhanan Yang Maha esa" yang mana memiliki kekuatan eksekutorial sama dengan putusan Pengadilan berkekuatan hukum tetap (inkracht). Terdapat satu pengecualian suatu grosse akta pengakuan hutang tidak dapat diterima, yaitu bilamana debitur tidak mengakui besaran jumlah hutang yang valid. Apabila debitur tidak mengakui, maka permohonan eksekusi grosse akta pengakuan hutang tidak diterima oleh Ketua Pengadilan dan dibuatkan Berita Acara serta Ketua Pengadilan memerintahkan untuk membuat gugatan baru, yaitu gugatan perdata.

Suatu grosse akta diberikan kepada akta hipotek dan akta utang piutang atau biasa disebut akta pengakuan hutang sebagaimana disebutkan dalam Pasal 224 HIR atau Pasal 258 RBg. Grosse akta selalu diberikan atas permintaan dari kreditor. Akta pengakuan hutang yang dibuat oleh Notaris pada bagian kepala aktanya memuat irah-irah yang sama bunyinya dengan putusan pengadilan yang telah berkekuatan hukum tetap, yaitu "Demi Keadilan 
Berdasarkan Ketuhanan Yang Maha Esa" dan bagian akhir aktanya ditulis "Diberikan sebagai grosse pertama atas permintaan (kreditor)" sehingga grosse akta tersebut memiliki kekuatan eksekutorial. ${ }^{20}$

Salinan dari akta hutang piutang atau akta pengakuan hutang notaril inilah yang memiliki kekuatan eksekutorial dan dinamakan dengan Grosse Akta Pengakuan Hutang Notaril. Notaris dalam hal ini diberi wewenang oleh UUJN sehingga kewenangan dari notaris dalam membuat grosse akta merupakan wewenang yang bersifat atributif 21 .

Lola Rosalina ${ }^{22}$ menjelaskan bahwa Notaris diberi kewenangan oleh UUJN untuk membuat grosse akta pengakuan hutang. Grosse akta ini jika merujuk pada Pasal 224 HIR atau Pasal 258 RBg memiliki kekuatan eksekutorial yang ditandai dengan adanya irah-irah eksekutorial pada bagian kepala akta sehingga dipersamakan dengan putusan pengadilan yang telah memiliki kekuatan hukum yang tetap.

Dilihat dari karakteristiknya, grosse akta yang dibuat oleh notaris tidak hanya berfungsi sebagai alat pembuktian di pengadilan jika terjadi sengketa atau perselisihan antara kreditor dan debitur, tapi juga dapat dijadikan alat untuk melakukan eksekusi terhadap harta benda debitur apabila debitur melakukan wanprestasi. Sebagaimana telah dijelaskan sebelumnya pada Bab II bahwa suatu akta yang dibuat oleh pejabat yang berwenang memiliki fungsi pembuktian yang kekuatan pembuktiannya dibedakan menjadi 3 (tiga), yakni kekuatan pembuktian lahiriah, kekuatan pembuktian formil, dan kekuatan pembuktian materil. Terkait konteks ini, maka grosse akta yang dibuat oleh notaris mengandung ketiga kekuatan pembuktian tersebut. Secara lahiriah, grosse akta sebagai suatu salinan dapat dijadikan sebagai alat bukti yang kedudukannya sama dengan minuta akta di hadapan persidangan sehingga hakim yang memeriksa perkara tidak perlu lagi meminta kepada para pihak untuk menghadirkan minuta akta di pengadilan. Kemudian secara formil, grosse akta yang dibuat oleh notaris dapat memberi kepastian tentang peristiwa bahwa para pihak melakukan apa yang dimuat dalam grosse akta. Sedangkan secara materil, grosse akta yang dibuat oleh notaris memberikan kepastian tentang materi dan peristiwa yang dimuat dalam akta bahwa para pihak menyatakan dan melakukan seperti yang dimuat dalam akta.

Kemudian sebagai alat bukti, grosse akta yang dibuat oleh notaris juga memiliki 3 (tiga) fungsi, yakni fungsi formil (formalitas causa), fungsi alat bukti (probationis causa), dan fungsi solemnie tatis causa. Secara formil, grosse akta yang dibuat oleh notaris

20 Situmorang dan Sitanggang, Grosse Akta Dalam Pembuktian dan Eksekusi, 18.

21 Sumber kewenangan ada 3, yakni Atribusi, Delegasi, dan Mandat. Atribusi artinya pemberian wewenang pemerintahan oleh pembuat undang-undang kepada organ pemerintahan. Delegasi artinya pelimpahan wewenang pemerintahan dari satu organ pemerintahan kepada organ pemerintahan lainnya. Sedangkan Mandat terjadi ketika organ pemerintahan mengizinkan kewenangannya dijalankan oleh organ lain atas namanya. Wewenang Notaris sebagai pejabat umum didapatkan dari UUJN sehingga sumber kewenangannya dikategorikan Atribusi. Meskipun Notaris bukanlah organ pemerintahan, namun kedudukan notaris dalam sistem ketatanegaraan adalah menjalankan sebagian kekuasaan negara di bidang hukum privat.

22 Lola Rosalina, Notaris/PPAT Kota Makassar. Wawancara Tanggal 20 Oktober 2019. 
memberikan keabsahan dan legalitas pada pengakuan seorang debitur atas adanya suatu hutang kepada kreditor. Atas dasar pengakuan ini, maka grosse akta memberikan pula keabsahan dan legalitas kepada kreditur untuk dapat langsung mengajukan permohonan eksekusi kepada pengadilan apabila debitur wanprestasi tanpa mengajukan gugatan terlebih dahulu. Dari sini, maka tampaklah fungsi grosse akta sebagai alat bukti yang dapat diajukan di hadapan hakim dalam hal kreditor mengajukan pemohon eksekusi. Dari sini tampak pula fungsi grosse akta sebagai solemnie tatis causa yang artinya merupakan satusatunya alat yang dapat dan sah membuktikan suatu hal atau peristiwa. Isi grosse akta yang memuat pengakuan debitur atas hutangnya kepada kreditor menjadi satu-satunya bukti yang otentik sehingga jika ada pihak yang menyangkalinya, maka ia harus membuktikan sebaliknya.

Kedudukan notaris dalam sistem ketatanegaraan Indonesia ditempatkan pada cabang kekuasaan eksekutif oleh karena notaris memberikan pelayanan umum kepada masyarakat dalam hal membantu pemerintah dalam menyediakan suatu surat atau akta yang berisi keterangan mengenai perbuatan hukum yang dilakukan oleh masyarakat secara privat. Sebagai bagian dari cabang kekuasaan eksekutif, kewenangan yang diberikan kepada Notaris adalah wewenang yang bersifat atributif sehingga notaris dapat menerbitkan grosse akta pengakuan hutang. Grosse akta pengakuan hutang sebagai produk hukum dari notaris yang notabene bagian dari eksekutif memang memiliki karakteristik yang sama dengan produk hukum yudikatif sehingga dalam eksekusinya diperlukan penetapan dari pengadilan sebagai bentuk legalitas dari pelaksanaan eksekusi grosse akta pengakuan hutang.

Adanya kewajiban untuk memperoleh penetapan pengadilan dalam eksekusi grosse akta pengakuan hutang adalah sebagai bentuk penegasan bahwa kekuasaan kehakiman yang salah satunya berisi penetapan dan pelaksanaan eksekusi adalah wewenang dan merupakan tugas dari lembaga peradilan yang menjalankan cabang kekuasaan yudikatif. Kekuasaan kehakiman di Indonesia merupakan kekuasaan yang independen sehingga untuk menjaga independensi kekuasaan kehakiman tersebut diterbitkan Ketetapan MPRRI Nomor X/MPR/1998 tentang Pokok-Pokok Reformasi Pembangunan Dalam Rangka Penyelamatan dan Normalisasi Kehidupan Nasional sebagai salah satu haluan negara. Ketetapan MPR-RI Nomor X/MPR/1998 ini menginginkan terwujudnya kekuasaan kehakiman yang merdeka dan supremasi hukum dalam kehidupan bermasyarakat, berbangsa, dan bernegara. Pada Ketetapan MPR-RI Nomor X/MPR/1998 ini, khususnya Bab C mengenai Hukum, ditegaskan perlunya reformasi di bidang hukum untuk mendukung penanggulangan krisis di bidang hukum. Salah satu amanat dalam Ketetapan MPR-RI Nomor X/MPR/1998 ini yang harus dijalankan adalah pemisahan yang tegas antara fungsi kekuasaan eksekutif dan fungsi kekuasaan yudikatif. Pemisahan ini dilaksanakan dengan mengalihkan organisasi, administratif, dan finansial badan-badan peradilan yang semula di bawah departemen-departemen yang bersangkutan menjadi di bawah kekuasaan Mahkamah Agung. 
Untuk itu, dalam konteks eksekusi grosse akta pengakuan hutang, maka penegasan kemerdekaan dan independensi badan peradilan serta penegasan pemisahan yang tegas antara fungsi kekuasaan eksekutif dan fungsi kekuasaan yudikatif dilakukan dalam bentuk kewajiban adanya penetapan dari pengadilan jika kreditor ingin mengeksekusi grosse akta pengakuan hutang. Penegasan ini sekaligus pula menegaskan kedudukan notaris sebagai pejabat umum yang menjalankan fungsi pelayanan umum kepada masyarakat yang merupakan bagian dari tugas dan fungsi cabang kekuasaan eksekutif.

\section{Hakikat Kedudukan Irah-Irah Eksekutorial Pada Grosse Akta Pengakuan Hutang Dalam Memberi Kepastian Hukum Bagi Kreditur}

Grosse akta pengakuan hutang mempunyai kekuatan eksekutorial, tetapi untuk melakukan eksekusi harus berdasarkan putusan hakim Pengadilan Negeri yang telah mempunyai kekuatan hukum tetap. Permohonan untuk dilakukannya eksekusi dapat berdasarkan Akta Pengakuan Hutang tersebut, namun pihak debitur sebagai termohon dapat melakukan perlawanan. ${ }^{23}$ Meskipun memakai irah-irah eksekutorial, eksekusi tidak dapat dilakukan hanya dengan berdasar pada akta pengakuan hutang terhadap harta debitur yang dijadikan sebagai jaminan, eksekusi dilakukan harus melalui Pengadilan Negeri sehingga dengan ini dapat dikatakan bahwa kekuatan hukum akta pengakuan hutang hanya sebatas mengikat debitur dan kreditor.

Atas dasar penjelasan sebagaimana diuraikan di atas, maka kedudukan irah-irah eksekutorial pada suatu grosse akta pengakuan hutang tidak mempunyai kekuatan eksekutorial langsung, tetapi harus melalui penetapan dari pengadilan. Namun demikian, kedudukan grosse akta pengakuan hutang yang memiliki irah-irah eksekutorial sebagai salinan dari suatu minuta akta berbeda dengan salinan dari akta-akta lainnya yang tidak memiliki irah-irah eksekutorial, yakni memiliki kekuatan pembuktian yang sama dengan minuta atau aslinya sehingga dalam proses pembuktian di pengadilan tidak lagi dibutuhkan minuta akta sebagai sumber terbitnya grosse akta pengakuan hutang tersebut. Berbeda dengan salinan akta-akta lainnya, dalam pembuktian di pengadilan dibutuhkan untuk dihadirkan minuta aktanya untuk dicocokkan dengan salinan akta yang dijadikan sebagai alat bukti oleh pihak-pihak yang bersengketa.

Selanjutnya jika disandingkan dengan putusan pengadilan, maka penulis dapat menjelaskan bahwa kekuatan hukum dari suatu grosse akta pengakuan hutang yang memiliki irah-irah eksekutorial hanya untuk memberikan kepastian hukum mengenai adanya suatu hubungan hukum utang piutang saja beserta dengan besaran utang debitur terhadap kreditor. Berbeda dengan putusan pengadilan, kepastian hukum yang diberikan oleh suatu putusan pengadilan adalah kepastian hukum yang bukan hanya mengenai kedudukan suatu hubungan hukum, tetapi termasuk pula kepastian hukum akan hak seseorang serta kepastian hukum atas pelaksanaan suatu eksekusi. Dalam konteks utang piutang, suatu putusan pengadilan akan memberikan kepastian hukum atas hubungan

23 Bambang Nurcahyo, Hakim Pengadilan Negeri Makassar. Wawancara Tanggal 29 Oktober 2019. 
hukum utang piutang antara kreditor dan debitur, kepastian hukum mengenai hak kreditor atas harta benda milik debitur, serta kepastian hukum atas pelaksanaan eksekusi harta benda milik debitur.

Sebagaimana telah dijelaskan sebelumnya bahwa tujuan hukum yang paling realistis adalah kepastian hukum. Kepastian hukum merupakan hak konstitusional setiap Warga Negara Indonesia sebagaimana ditentukan dalam Pasal 28D UUD NRI 1945 bahwa "Setiap orang berhak atas pengakuan, jaminan perlindungan dan kepastian hukum yang adil serta perlakuan yang sama di hadapan hukum". Untuk itu, maka negara berkewajiban memberikan perlindungan terhadap hak asasi manusia sebagaimana diatur dalam Pasal 28I ayat (4) UUD NRI 1945 bahwa "Perlindungan, pemajuan, penegakan, dan pemenuhan hak asasi manusia adalah tanggung jawab negara, terutama pemerintah".

Permasalahan grosse akta pengakuan hutang yang sampai saat ini masih terjadi adalah adanya penafsiran yang berbeda-beda mengenai substansi dari Pasal 224 HIR atau Pasal 258 RBg. Hal ini menyebabkan pelaksanaan eksekusi menggunakan grosse akta pengakuan hutang menjadi berbeda-beda pula di setiap Pengadilan Negeri. Tidak terpenuhinya syarat formil dan syarat materiil juga menyebabkan grosse akta pengakuan hutang tidak diterima oleh Pengadilan Negeri. Perlu diketahui oleh pihak-pihak yang berkepentingan baik debitur maupun kreditor bahwa permohonan eksekusi grosse akta pengakuan dapat tidak diterima karena ketika dilakukan aanmaning oleh Ketua Pengadilan Negeri, debitur tidak mengakui jumlah hutang yang pasti sehingga permohonan tidak dapat diterima dan kepada kreditur dimohon agar mengajukan gugatan baru, yaitu gugatan perdata biasa.

Bambang Nurcahyo ${ }^{24}$ juga mengungkapkan bahwa permasalahan dalam pelaksanaan eksekusi grosse akta pengakuan hutang juga muncul ketika adanya perlawanan eksekusi yang dilakukan oleh pihak ketiga dengan barang yang menjadi objek eksekusi tersebut. Pihak ketiga mengaku bahwa barang yang dijadikan objek eksekusi tersebut adalah miliknya dan peristiwa seperti ini tidak jarang terjadi ketika pelaksanaan eksekusi sedang berlangsung. ${ }^{25}$ Namun demikian, Pengadilan memperjelas bahwa pelaksanaan eksekusi tidak boleh dihalang-halangi oleh siapa pun. Apabila dihalangi, maka pihak tersebut harus mengajukan perlawanan sita sendiri kepada pengadilan.

Problematika eksekusi grosse akta yang terjadi sampai saat ini pada prinsipnya disebabkan oleh karena pemahaman yang berbeda mengenai grosse akta itu sendiri. Tidak sedikit pihak yang beranggapan bahwa eksekusi terhadap suatu grosse akta dapat dilakukan secara langsung oleh karena grosse akta memiliki irah-irah eksekutorial. Tidak

24 Bambang Nurcahyo, Hakim Pengadilan Negeri Makassar. Wawancara Tanggal 29 Oktober 2019.

25 Ni Putu Teresa Giovana, "Standing Commitment of Sale and Purchase Agreement (PPJB) in Purchasing Flats Unit as Legal Protection for Consumers," Substantive Justice International Journal of Law (2019): 23. 
sedikit pula pihak yang beranggapan bahwa sudah sepatutnya eksekusi terhadap suatu grosse akta harus dilakukan dengan fiat pengadilan ataupun melalui parate eksekusi26.

Sebagaimana telah penulis uraikan sebelumnya bahwa sesungguhnya eksekusi terhadap suatu grosse akta harus dilakukan dengan mendapatkan penetapan dari pengadilan terlebih dahulu. Hal ini sebagai bentuk pengawasan pengadilan terhadap pelaksanaan grosse akta pengakuan hutang oleh karena grosse akta pengakuan hutang merupakan produk hukum notaris yang memiliki irah-irah eksekutorial. Oleh karena eksekusi grosse akta dilakukan dengan mendapatkan penetapan dari pengadilan terlebih dahulu, maka jelas bahwa hakim memiliki kewenangan untuk menilai suatu grosse akta pengakuan hutang apakah dapat dilakukan eksekusi atau tidak.

Dalam Pasal 5 ayat (1) Undang-Undang Nomor 48 Tahun 2009 tentang kekuasaan kehakiman ditentukan bahwa "Hakim dan hakim konstitusi wajib menggali, mengikuti dan memahami nilai-nilai hukum dan rasa keadilan yang hidup dalam masyarakat". Kemudian dalam Pasal 11 ayat (1) Undang-Undang Nomor 48 Tahun 2009 tentang kekuasaan kehakiman ditentukan pula bahwa "Pengadilan memeriksa, mengadili, dan memutus perkara dengan susunan majelis sekurang-kurangnya 3 (tiga) orang hakim, kecuali undang-undang menentukan lain". Dari ketentuan ini dapat dilihat bahwa pengadilan melalui hakim-hakimnya berwenang untuk memeriksa, mengadili, dan memutus suatu perkara.

Hakim dalam menerima permohonan mengenai eksekusi terhadap suatu grosse akta pengakuan hutang juga perlu untuk memeriksa kembali permohonan yang diajukan oleh kreditor. Memang dalam hukum acara perdata, tuntutan hak yang berupa permohonan tidak mengandung sengketa di dalamnya. Namun dalam konteks permohonan eksekusi grosse akta pengakuan hutang, sejatinya terdapat sengketa atau perselisihan antara kreditur dengan debitur, paling minimal bentuk perselisihan tersebut adalah keberatan dari kreditor atas perbuatan wanprestasi yang dilakukan oleh debitur. Untuk itu, maka hakim perlu memeriksa kembali kebenaran isi permohonan dari kreditor atas eksekusi grosse akta pengakuan hutang. ${ }^{27}$

Pelaksanaan eksekusi terhadap grosse akta pengakuan hutang dilakukan apabila debitur tidak melaksanakan prestasi yang diperjanjikan. Persoalan yang menjadi akar persoalan atas perbedaan pandangan dalam eksekusi terhadap grosse akta pengakuan hutang lebih disebabkan tafsiran terhadap Pasal 224 HIR atau Pasal 258 RBg. Sehubungan dengan eksekusi grosse pengakuan hutang yang masih sering bermasalah, M. Yahya Harahap ${ }^{28}$

26 Fiat Pengadilan atau dengan nama lain Fiat Eksekusi diartikan sebagai penetapan pengadilan untuk melaksanakan putusan pengadilan jika pihak yang dikalahkan dalam putusan menolak untuk melaksanakannya secara sukarela. Sedangkan Parate eksekusi atau eksekusi langsung adalah Eksekusi terhadap objek jaminan dengan menjual langsung objek tersebut oleh kreditur melalui lembaga pelelangan umum tanpa melalui ijin atau perintah eksekusi dari ketua pengadilan. Berdasakan definisi tersebut, maka Parate Eksekusi menurut penulis dapat dilakukan tanpa melakukan Fiat Pengadilan.

27 Bambang Nurcahyo, Hakim Pengadilan Negeri Makassar. Wawancara Tanggal 29 Oktober 2019.

28 M. Yahya Harahap, Hukum Acara Perdata Tentang Gugatan, Persidangan, Penyitaan, Pembuktian, dan Putusan Pengadilan (Jakarta: Sinar Grafika, 2007), 305. 
menjelaskan bahwa hal terpenting yang harus diperhatikan agar eksekusi grosse akta pengakuan hutang berjalan lancar, yakni syarat sahnya grosse akta pengakuan hutang, yakni:

a. Syarat formal. Syarat formal yang dimaksud di sini adalah grosse akta harus dibuat dalam bentuk akta notaril (otentik). Grosse akta selain dibuat dalam bentuk akta notaris, juga harus memuat frasa "Demi Keadilan Berdasarkan Ketuhanan yang Maha Esa" (sebab hanya dengan irah-irah tersebut grosse akta dapat dilaksanakan eksekusi karena kekuatannya sama dengan putusan pengadilan yang telah inkracht van gewijsde).

b. Syarat materil, merupakan syarat yang menyangkut rumusan dan isi yang harus dipenuhi oleh grosse akta tersebut. Syarat-syarat materil suatu akta harus memuat:

- Merupakan pernyataan sepihak dari debitur yang meliputi (a) adanya pengakuan berhutang dari debitur; (b) wajib membayar pada waktu yang ditentukan; dan (c) merupakan akta pengakuan hutang, artinya tidak bercampur aduk dengan akta hak tanggungan (sesuai dengan putusan Mahkamah Agung No. 1313 K/Pdt/1985 tanggal 9 Desember 1987).

- Jumlah hutang sudah pasti (fixed loan) tidak boleh berupa kredit plapond. Artinya pada saat grosse akta itu dibuat jumlah hutang sudah terealisasi (yang terdiri dari hutang pokok ditambah bunga) sesuai dengan putusan Mahkamah Agung No. $1313 \mathrm{~K} / \mathrm{Pdt} / 1985$.

Lebih lanjut lagi M. Yahya Harahap menjelaskan bahwa ada beberapa hal yang menjadi patokan sebagai dasar hukum untuk melakukan eksekusi terhadap grosse akta pengakuan hutang, yakni:

1. Harus dibuat di Indonesia;

2. Tidak berupa legalisir notaris terhadap akta di bawah tangan. Hal ini sebagaimana putusan Mahkamah Agung RI. Nomor 3992 K/Pdt/1986 tanggal 28 September 1988;

3. Memenuhi syarat formal grosse akta pengakuan hutang:

- Berbentuk akta notaris;

- Memuat titel eksekutorial.

4. Memenuhi syarat materil:

- Pengakuan hutang sepihak dari debitur;

- $\quad$ Berupa fixet loan;

- Jumlah hutang pokok + bunga sudah pasti. ${ }^{29}$

Grosse akta pengakuan hutang telah memberikan perlindungan hukum yang cukup apabila grosse akta pengakuan hutang tersebut telah memenuhi syarat formal dan syarat materil dari suatu grosse akta. Apabila tidak dipenuhinya apa yang menjadi syarat formil dan materil dari grosse akta, maka grosse akta itu akan kehilangan kekuatan

29 Ibid., 310. 
eksekutorialnya sehingga kekuatan akta itu hanya dapat dilakukan dengan gugatan perdata biasa.

Suatu grosse akta pengakuan hutang harus ditandatangani oleh debitur beserta suami/istrinya apabila ia telah menikah. Pasal 119 KUHPerdata telah menentukan bahwa sejak dilangsungkannya perkawinan, maka demi hukum terjadi persatuan harta secara bulat kecuali ditentukan lain oleh para pihak dalam suatu perjanjian kawin. Ketentuan Pasal 119 KUHPerdata ini memaksa seorang debitur yang akan mengakui suatu hutang dalam suatu akta pengakuan hutang wajib menyertakan pasangannya untuk ikut menandatangani akta pengakuan hutang tersebut, kecuali jika debitur itu memiliki perjanjian kawin.

Sebagaimana telah dijelaskan sebelumnya pada latar belakang masalah bahwa pada Tahun 1985, Mahkamah Agung RI mengeluarkan Fatwa Nomor 213/229/85/II/Um.Tu/Pdt tertanggal 16 April 1985 yang menyatakan bahwa suatu grosse akta tidak dapat ditambah persyaratan-persyaratan lain selain berisi pengakuan hutang saja dari debitur dengan perumusan semata-mata suatu kewajiban untuk membayar atau melunaskan sejumlah uang tertentu. Hal ini berarti dalam suatu grosse akta tidak dapat ditambahkan persyaratan-persyaratan atau klausul-klausul lain yang sifatnya berbentuk perjanjian. Persyaratan yang berbentuk perjanjian sebagaimana dimaksud antara lain:30

a. Diperjanjikan bahwa selama perjanjian berjalan atau berlaku, pihak debitur selaku pemberi jaminan diwajibkan mengasuransikan apa yang dijaminkan tersebut pada perusahaan asuransi yang ditunjuk atau disetujui oleh pihak kreditur atau bank.

b. Diperjanjikan bahwa biaya pembuatan akta dan segala biaya lainnya yang berhubungan dengan perjanjian penambahan kredit pengakuan hutang, menjadi tanggungan dari dan harus dibayar oleh pihak debitur.

c. Diperjanjikan bahwa jika debitur lalai membayar, maka segala biaya-biaya pengacara atau kuasa dari pihak kreditor untuk menagih kepada pihak debitur menjadi tanggungan dan wajib dibayar oleh pihak debitur.

d. Diperjanjikan bahwa kreditur sebelum waktunya pelunasan dapat menagih hutangnya atau sewaktu-waktu berhak mengakhiri perjanjian atau jumlah hutang yang berhutang tersebut dapat ditagih dan harus dibayar seketika dan sekaligus jika debitur pailit, barang jaminan dikenakan suatu sitaan penjualan, atau barang jaminan berkurang sehingga tidak mencukupi sebagai jaminan hutang.

Grosse akta pengakuan hutang mempunyai nilai eksekutorial, sehingga apabila debitur wanprestasi, maka dapat dilakukan eksekusi setelah memperoleh fiat pengadilan negeri. Dapat ditegaskan bahwa perlunya fiat pengadilan karena kedudukan grosse akta pengakuan hutang dipersamakan dengan suatu putusan pengadilan yang mempunyai kekuatan hukum tetap (inkracht van gewijsde). Dengan grosse akta pengakuan hutang yang kedudukannya sama dengan putusan pengadilan, maka untuk pelaksanaan

30 Ibid., 127. 
eksekusinya diperlukan fiat eksekusi dari ketua pengadilan negeri. Eksekusi terhadap jaminan kredit berdasarkan grosse akta pengakuan hutang yang dibuat oleh Notaris tidak dapat dilakukan secara serta merta oleh kreditor meskipun grosse akta pengakuan hutang tersebut memakai irah-irah "Demi Keadilan Berdasarkan Ketuhanan Yang Maha Esa" seperti halnya putusan pengadilan.

Makna dari mempunyai kekuatan sama dengan putusan pengadilan yang telah inkracht van gewijsde ini artinya bahwa pelaksanaan eksekusinya harus dengan fiat pengadilan karena dipersamakan dengan suatu putusan. Kedudukan istimewa dari grosse akta pengakuan hutang tidak boleh menghapus kewenangan pengadilan dalam hal wewenang untuk melaksanakan eksekusi, termasuk eksekusi terhadap grosse akta pengakuan hutang. Suatu putusan hakim saja yang sudah jelas melalui proses dan tahapan yang panjang untuk dapat menjadi putusan, pelaksanaan eksekusinya diperlukan izin dari pengadilan. Apalagi grosse akta pengakuan hutang yang pada hakikatnya bukan merupakan suatu putusan pengadilan, namun hanya karena kedudukan grosse akta yang oleh undang-undang dipersamakan dengan putusan pengadilan yang telah inkracht van gewijsde sehingga grosse akta tetap membutuhkan penetapan dari pengadilan.

Dengan demikian untuk pelaksanaan eksekusi suatu grosse akta pengakuan hutang diperlukan suatu fiat pengadilan. Hal ini sebagaimana dinyatakan pula oleh Herowati Pusoko $^{31}$ bahwa pengaturan eksekusi menurut Pasal 224 HIR adalah eksekusi yang ditujukan kepada grosse akta hipotek dan grosse akta pengakuan hutang. Kedua grosse akta tersebut memang dimaksudkan untuk mempunyai hak eksekutorial yang berarti bahwa kedua grosse akta tersebut mempunyai kekuatan sebagai putusan pengadilan yang mempunyai kekuatan hukum yang tetap. Untuk itu, maka eksekusinya tunduk dan patuh sebagaimana pelaksanaan suatu putusan pengadilan yang harus dilaksanakan atas perintah ketua pengadilan negeri.

\section{Kesimpulan}

Kewenangan notaris dalam membuat grosse akta pengakuan hutang yang memiliki irahirah eksekutorial dikaitkan dengan kedudukan notaris sebagai pejabat umum adalah bersifat atributif. Grosse akta pengakuan hutang sebagai produk hukum dari notaris yang notabene bagian dari eksekutif memiliki karakteristik yang sama dengan produk hukum yudikatif sehingga dalam eksekusinya diperlukan penetapan dari pengadilan sebagai bentuk legalitas dari pelaksanaan eksekusi grosse akta pengakuan hutang. Irah-irah eksekutorial pada grosse akta pengakuan hutang pada hakikatnya tidak mempunyai kekuatan eksekutorial langsung, tetapi harus melalui penetapan dari pengadilan sebagai bentuk legalitas pelaksanaan eksekusi. Namun demikian, kedudukan grosse akta pengakuan hutang yang memiliki irah-irah eksekutorial sebagai salinan dari suatu minuta akta berbeda dengan salinan dari akta-akta lainnya yang tidak memiliki irah-irah eksekutorial, yakni memiliki kekuatan pembuktian yang sama dengan minuta atau aslinya

31 Herowati Poesoko, Parate Executir Obyek Hak Tanggungan (Inkonsistensi, Konflik Norma dan Kesesatan Pealaran dalam UUHT) (Yogyakarta: Laksbang Pressindo, 2007), 9-10. 
sehingga dalam proses pembuktian di pengadilan tidak lagi dibutuhkan minuta akta sebagai sumber terbitnya grosse akta pengakuan hutang tersebut. Kekuatan hukum dari suatu grosse akta pengakuan hutang yang memiliki irah-irah eksekutorial hanya untuk memberikan kepastian hukum mengenai adanya suatu hubungan hukum utang piutang saja serta memberikan kepastian hukum kepada kreditor perihal eksekusinya yang tidak perlu lagi melalui pengajuan gugatan, namun hanya didasarkan atas permohonan kreditor.

Sebagai rekomendasi penelitian, diperlukan penegasan dalam suatu peraturan perundang-undangan, termasuk dalam UUJN bahwa suatu grosse akta pengakuan hutang tidak memiliki kekuatan eksekutorial langsung, namun memerlukan penetapan dari pengadilan terlebih dahulu, sehingga memberikan kepastian hukum dalam pelaksanaan eksekusinya. Selain itu, diharapkan kepada Mahkamah Agung RI sebagai lembaga yang bersinggungan dengan masalah pelaksanaan eksekusi terhadap akta-akta otentik khususnya grosse akta pengakuan hutang dapat memberikan pedoman baku tata cara pelaksanaan eksekusinya grosse akta pengakuan hutang dalam hukum acara perdata di Indonesia sehingga pihak yang berkepentingan tidak memberikan penafsiran sendiri sesuai kepentingannya.

\section{Daftar Pustaka}

Anand, Ghansam. Karakteristik Jabatan Notaris di Indonesia. Surabaya: Zifatama Publisher, 2014.

Arifin, Mochammad Taufiq. "Eksekusi Grosse Akta Merujuk Pada Pasal 224 HIR dan Putusan Mahkamah Agung." Jurnal Hukum dan Kenotariatan 3, no. 1 (2019).

Arisaputra, Muhammad Ilham, Muhammad Ashri, Kasman Abdullah, dan Dian Utami Mas Bakar. "Akuntabilitas Administrasi Pertanahan dalam Penerbitan Sertifikat." Mimbar Hukum 29, no. 2 (2017).

Giovana, Ni Putu Teresa. "Standing Commitment of Sale and Purchase Agreement (PPJB) in Purchasing Flats Unit as Legal Protection for Consumers." Substantive Justice International Journal of Law (2019).

Harahap, M. Yahya. Hukum Acara Perdata Tentang Gugatan, Persidangan, Penyitaan, Pembuktian, dan Putusan Pengadilan. Jakarta: Sinar Grafika, 2007.

- - - Ruang Lingkup Permasalahan Eksekusi Bidang Perdata. 5 ed. Jakarta: Gramedia Pustaka Utama, 1996.

Hendratno, Edie Toet. Negara Kesatuan, Desentralisasi ,dan Federalisme. Yogyakarta: Graha Ilmu, 2009.

Ilyas, Anshori, Muhammad Ilham Arisaputra, dan Mustafa Bola. Kontrak Publik. Makassar: UPT Unhas Press, 2017.

Marzuki, Peter Mahmud. Penelitian Hukum. Jakarta: Kencana Prenada Media Group, 2009.

Pittaloka, Elza Sylvania, dan Pranoto. "Permasalahan dalam Pelaksanaan Eksekusi Grosse Akta Pengakuan Hutang." Jurnal Privat Law 4, no. 1 (2016). 
Poesoko, Herowati. Parate Executir Obyek Hak Tanggungan (Inkonsistensi, Konflik Norma dan Kesesatan Pealaran dalam UUHT). Yogyakarta: Laksbang Pressindo, 2007.

Rangian, Shendy Vianni. "Pelaksanaan Eksekusi Grosse Akta Pengakuan Hutang Dalam Penyelesaian Sengketa Kredit Macet Perbankan." Calyptra: Jurnal Ilmiah Mahasiswa Universitas Surabaya 4, no. 1 (2015).

Saraswati, Ananda Fitki Ayu. "Dilematis Eksekusi Hak Tanggungan melalui Parate Executie dan Eksekusi melalui Grosse Akta.” Repertorium 2, no. 2 (2015): 51-59.

Setiabudhi, D. O., T. N. Palilingan, Irwansyah, F. Maramis, dan Ahsan Yunus. "Collective land certification policy for improving good land governance." IOP Conference Series: Earth and Environmental Science 343, no. 1 (2019).

Situmorang, Victor M., dan Cormentyna Sitanggang. Grosse Akta Dalam Pembuktian dan Eksekusi. Jakarta: Rineka Cipta, 1998.

Wuryanto, Riyo, dan Noor Saptanti. "Efektivitas Grosse Akta Pengakuan Hutang dalam Praktik Pemberian Kredit Perbankan di Surakarta." Jurnal Repertorium 5, no. 1 (2018). 